\title{
Drivers for Internationalization in Georgian Higher Education
}

\author{
Pusa Nastase
}

This research investigates the main drivers for the integration of international elements in the Georgian higher education. The internationalization of higher education in many regions of the world has been widely documented in the past three decades. As often noted, internationalization is somewhat of a one-size-fits-all term used to describe diverse processes and programs including: "[student and faculty] mobility, mutual influence of higher education systems, and internationalization of the substance of teaching and learning to institutional strategies, knowledge transfer, cooperation and competition, and national and supranational policies" (Kehm and Teichler 2007). More recently, internationalization has been defined as "the intentional process of integrating an international, intercultural or global dimension into the purpose, functions and delivery of post-secondary education, in order to enhance the quality of education and research for all students and staff, and to make a meaningful contribution to society" (de Wit et al. 2015).

In Europe, internationalization has been incrementally adopted for a few decades now, starting in the 1980s. At macro level, internationalization programs served both economic and political purposes. For instance, student mobilities helped the EU economy by preparing European students to work in other member countries and make the EU economy more global competitive. Other initiatives (such as TEMPUS) achieved the political goals of diminishing the gap between the new candidate countries and older Member States. ${ }^{1}$ The expansion led by internationalization started to be questioned once the unintended consequences of this process became obvious: the commercialization of research, diploma and accreditation mills and the impact of international rankings on institutions (Knight 2003). Confirming the predictions of the earlier warning signs, Altbach and de Wit (2018) reflected more recently that "the unlimited growth of internationalization of all kinds-including massive global student mobility, the expansion of branch campuses, franchised and joint degrees, the use of English as a language for teaching and research worldwide, and many

\footnotetext{
${ }^{1} \mathrm{http}: / /$ internacional.ipvc.pt/sites/default/files/Tempus\%4020\%20-\%20A\%20Retrospective $\% 20$ of $\% 20$ the $\% 20$ Tempus $\% 20$ Programme $\% 20$ over $\% 20$ the $\% 20$ Past $\% 2020 \% 20$ Years.pdf.
}

P. Nastase $(\bowtie)$

Central European University, Budapest, Hungary

e-mail: nastasep@ceu.edu 
other elements-appears to have come to a rather abrupt end, especially in Europe and North America" (p. 2).

Outside the EU, Georgia has also placed internalization high on the national higher education agenda. While for other EU members internationalization has arguably a financial component (due to the considerable EU funding available for research in particular) this is less so in the case of Georgia, which has limited access to EU funding. This study explores the main drivers of internationalization in Georgian higher education with a view of finding out why it is a national priority at the same time when many other countries experience a reverse of internationalization policies.

\section{Internationalization in Georgian Higher Education}

The internationalization agenda in Georgia has been promoted for the past several years as an effort to align with Western higher education and to overcome the challenges from the past. Some of these challenges were related to the Soviet time when universities did not train students to be civic-minded but to work in the planned economy (Sharvashidze 2005), with the interrupted tradition of teaching social sciences and the different organization of doctoral studies cycle (Kovács 2014). Some other challenges have to do with the economic difficulties of the 1990s when the severe underfunding of universities resulted in an underperforming higher education sector that had difficulties attracting good faculty and lacked the facilities needed for students. The so-called Rose Revolution of 2003 reversed this course. President Saakashvili declared that higher education needed change and described efforts to stem corruption and increase the transparency of the sector from admission exams to faculty appointments (2006). Just like in the case of Armenia (Matei et al. 2013) the rapprochement to the EU was viewed as a priority for the country, and higher education was considered as a tool to achieve this goal.

A major step that confirmed the "European" trajectory and the Saakashvili government's educational reform initiatives (Jawad 2005) was made in 2005 when the enlargement of EHEA towards the East (Armenia, Azerbaijan, Georgia, Moldova and Ukraine) took place. In the beginning, the motivation of European Partnership countries for joining the Bologna Process was used either to increase EU integration or to benefit from the financial advantages in the field of higher education (Toderas and Stavaru 2018). As noted by Dobbins and Khachatryan in the case of Eastern Partnership countries, the Bologna Process is a mechanism which has a convergencepromoting force (2015).

In later years though, Georgia, in particular, has expressed the intention to join EU and made efforts to further bridge the gap in higher education. In June 2019, the European Quality Assurance Register (EQAR) Committee concluded that the Georgian National Center for Education Quality NCEQE complies substantially with the ESG as a whole and approved the application for inclusion on the Register valid until 2024. Georgia becomes one of the two Eastern Partnership countries (after 
Armenia) to join EQAR, the rest of the agencies from Eastern Partnership countries are only affiliated.

Another tool to bridge the gap with the EU countries has been through the use of mobilities. The official statistics of the European Commission show a significant raise in the number of Erasmus mobilities: Georgian students and staff moving to Europe between 2015 and 2018 totalled 3613, increasing steadily between 695 in 2015 to 1109 in 2018. The total number of students and staff moving to Georgia on an Erasmus mobility was of 1973 for the same period, with a significant increase from 2015 (190) to 2019 (699)_-data from the official statistics of the European Commission. Overall Georgia has attracted $24 \%$ of the total budget for international credit mobilities available for Eastern Partnership countries, more than their regional neighbours Azerbaijan (8\%) and Armenia (12\%) combined. $^{2}$

With regard to the foreign students pursuing degrees in Georgia, data provided by the Ministry shows in 2019 a number of 12945 foreign students (an increase from 9439 in 2017$)^{3}$ with the majority of them coming from India (6820 in 2019, an increase from 2895 recorded in 2017), followed by Azerbaijan (1475), Iran (546), Iraq (544), Israel (532) and Nigeria (523).

Georgian students have also pursued degrees abroad funded by using their own resources and through state scholarships. In 2014, the International Education Center was set up with the purpose of supporting young Georgian in studying abroad. The Center has awarded over 500 scholarships to study in 26 countries, with the most students opting for the U.S.A. (88 fellows), the U.K. (75 fellows), Hungary (75 fellows) and France (40 fellows) ${ }^{4}$ under the understanding that scholarship recipients will return to work in Georgia after graduating. Interestingly, even before this funding scheme produced graduates, it was shown that Georgians studying abroad were returning in high numbers. A comparative study on the Georgian and Moldovan alumni of foreign universities (Campbell 2016) estimated that 80-90\% of Georgians return to live and work in their home country (almost double than in Moldova) which increases the pool of candidates for faculty positions and further bridge the gap with their Western counterparts. Alumni are incentivized to return also by programs designed to support their re-integration such as the one run by the German development agency GIZ; the local GIZ office in Georgia helps graduates of German universities to identify suitable jobs and tops up their wages for 2 years if they choose to work in the public or non-profit sectors.

Academic positions for returnees can be found not only in state universities but also in private ones which have more flexibility to offer better salaries. One of the new institutions, which is perhaps symbolic for the drive to internationalize, is the establishment in 2014 of the Tbilisi campus of San Diego State University, offer-

\footnotetext{
${ }^{2} \mathrm{https}: / /$ ec.europa.eu/programmes/erasmus-plus/resources/documents/country-factsheetgeorgia_en, consulted January 20, 2020.

${ }^{3}$ According to official data obtained for this study from the Ministry of Education-actualized for November 2019.

${ }^{4}$ http://iec.gov.ge/en-us/About-us/Statistics Consulted January 10, 2020.
} 
ing undergraduate degrees in several engineering fields to Georgian and foreigner students with support from the US-funded Millennium Fund.

However, while the pace and achievements are incontestable, there are also voices drawing attention to the fact that the Bologna-inspired reforms were introduced in order to gain international recognition but have triggered in fact only a symbolic system-change without deep transformation. Building on institutionalism theories (Mayer and Rowan 1977) Jibladze (2017) -herself one of the alumni returning to Georgia with foreign degrees, has noted that the changes of the higher education system were, in fact, less transformative and that they instead created decoupled institutions. She describes institutions having the appearance of their Western counterparts while holding onto a path- dependent core, similar to impressions collected in other former communist countries (see Nastase 2015).

To sum up, significant reforms were adopted in Georgian higher education, leading to increased transparency, less corruption and diversification of higher education sector. While certain voices have raised warnings about some of these changes being rather cosmetic than systemic, there are undeniable changes in the Georgian education landscape. In this context, the next sections will focus on what drives internationalization and how is it linked to the changes so far and with Georgia's aspirations as a country. research (Campbell and Gorgodze 2016) found that ${ }^{5}$ the three main engines driving internationalization efforts in the country were percived to be (1) western influences, (2) national university accreditation processes, and (3) faculty and students returning from abroad. In this study I try to see whether the political will and the funding allocated changed this perception and to bring additional perspectives on internationalisation in universities outside the capital.

\section{Research Design}

Following Knight (2004) suggestion to investigate internationalization looking both at the top process (national and institutional) and the bottom (institutional and individual), interviews were conducted with 19 higher education professionals including a former Deputy Minister, the Rector of Georgia's largest university from the capital, the Deputy Rector from one of the largest universities outside the capital (in the Adjara region), a high ranking leader from San Diego University Georgia, a Head of Department from the Ministry of Education, a high ranking official from the International Education Center (the state agency in charge with managing hundreds of scholarships for Georgian students studying abroad), two senior staff members from International Offices in two separate universities, an official from the GIZ-Georgia (the German agency for international development) and ten faculty at all levels of seniority in four of the largest universities. The semi-structured interviews were conducted in 2018 and 2019, in English, in person (9/19) and by Skype (10/19). The

\footnotetext{
${ }^{5}$ According to 18 respondents from Georgian universities and governmental agencies (instructors, administrators, and managers of programs related to internationalization).
} 
transcripts of interviews were sent to the interviewees for their approval. The interviewees were asked what drives the internationalization of Georgian education in their opinion, and what evidence is there to support their view. Most of the participants at institutional level offered both the institutional perspective on internationalization and their personal one-either as staff member or as faculty.

Additionally, Ministry of Education documents and relevant websites were reviewed, among them the Study in Georgia program website and universities' webpages to gather and corroborate information.

\section{Key Findings}

The interviewees were asked to reflect on the drivers for internationalization and to estimate their importance and urgency as seen from their own perspective as policy-makers, faculty or officials. They were also asked to provide as much as possible evidence substantiating their views. The picture they provided was relatively uniform with most of them agreeing on a limited number of drivers as outlined below.

\section{Higher Education as a Tool for Political Agenda}

Most participants indicated as the main driver for internationalization the political will for alignment with Western nations and particularly with the European Union. The former Minister of Education noted that internationalization of education is seen as a gateway to EU. For this reason the current Minister of Education ${ }^{6}$ has made the statement in a meeting with EU Commissioner Navracsics that Georgia aims at becoming Erasmus Program Country in the future and not just Erasmus Partner Country as it is now. At this stage the experts from both parts (Georgia -EU) are working on a timetable and conditions to be met for this to happen. Other interviewees noted that the desire to get closer to the EU is only logical because this is where we belong (International office staff member) and what else is there for us, this is the logical path (faculty member)?

Part of this national narrative is the lack of academic ties with Russia, the former colleagues and partners for many years, whose language many Georgian academics still speak (although this is no longer the case with younger generations). The political factor was invariably quoted as the main reason for the lack of formal ties with Russian institutions. Both faculty and staff agreed that beyond the political stance the Georgian society has a lack of trust in Russia due to the occupation of some Georgian territories, and initiating formal relations with Russian partners might create tensions in society and reflect poorly on universities. One staff member noted that collaboration exists in multi-lateral formats but not bilateral because bilateral relations need to be both ways: for Georgians is difficult to go to Russia (due to Russian visa) and they do not feel that good there. Additionally, a faculty member noted that social

\footnotetext{
${ }^{6}$ In November 10, 2019.
} 
sciences are much politicized in Russia and it makes sense to engage with partners that are serious about real research.

Nevertheless, Georgia's desire to increase ties with the EU affects its internationalization efforts due to conflicting restrictions from areas other than higher education: for instance, in order to align with EU standards in the field of immigration and border control, many university applicants from countries like Libya, Nigeria, Iran, Saudi Arabia experienced visa problems, and a high number was not able to attend the university because their visa application was turned down. As the representative from the San Diego State University (SDSU) in Georgia noted: many families in countries like Nigeria or Libya are looking for a safe country with affordable education to send their children too and Georgia has a lot to offer and it is very attractive for them. But the visa requirements also depend on Georgia's EU aspirations and the criteria they need to meet in this regard, so they walk a tight line that does not depend entirely on them.

Moreover, the immigration-related requirements imposed by EU might affect Georgia's aspiration to become a regional hub. The former Deputy Minister noted that we not only want to be close to EU, but to maintain good relations with the regional neighbours and to become a regional hub for higher education but not only. We cultivate relations with countries further afield in Asia and Africa with the same intentions of attracting them as higher education clients and partners in other fields.

\subsection{Higher Education as an Export Product}

Another driver given by many participants as being very important is the financial aspect. This has two major components: the desire to attract EU funding for projects and mobilities and the income brought by foreign students paying high fees.

First, all participants to the study (with one exception) mentioned the severe underfunding from the not so distant past, and the effects it had on the universities. The SDSU official noted that Georgian universities were hit very hard by the underfunding from the past, particularly in STEM fields where investment is needed to keep up. Their laboratories and facilities mandatory for science disciplines were hit the hardest. A faculty member also noted that going to conferences abroad or accessing journals was very difficult, and it still is for some universities that are smaller and less financially stable. Another faculty member reflected that we absolutely need to be part of EU projects, especially large ones that expose us to good partners because funding for research is still very limited in Georgia. Yet another faculty member noted that being part of the EU projects allows us to have conditions similar to those in EU countries, so it bridges the gap in terms of research quality ... at our department getting EU funded projects is a priority. Very often they come with enormous bureaucracy but they are still worth it because we would not be able to cover many activities from own sources.

The rector I interviewed noted that for his comprehensive university the income from international students does not make a big impact, but in medical schools they 
pay more than 3 times higher tuition fees than local students $(7000+$ Lari vs. 2250 Larifor domestic students). The same view was shared by the official from the SDSU who noted that foreign students pay fees that are also used to subsidize Georgian students' studies. One faculty member noted that we are way cheaper than many Western universities, but still the income foreign students bring can have an impact. This is why we need to increase the quality not only of what happens in the classroom but also offacilities. The Rector also indicated that his institution is currently building dormitories with pools, sport facilities and all technology expected. They expected that by attracting international students the tuition fee will help pay for the facilities in the longer term.

The recruitment of foreign students has been made a priority in 2004 through a governmental program titled Study in Georgia. The website lists (9 November 2019) 109 English language programs ( 55 undergraduate, 43 Masters and 11 doctoral programs) and 7 Russian language programs at institutions throughout Georgia but no opportunities for scholarships (although institutions like International School of Economics have available a limited number of merit- based scholarships). The program was launched with great expectations, but it seems to have achieved less than initially planned, partially because of the unfit strategy for recruitment and partially due to limited coordination between Ministry and universities. The official from International Education Center noted that some 20 coordinators were sent around the world to recruit students, but this strategy did not pay off. They could try helping universities to recruit rather than have external agents recruit on behalf of universities.

Despite challenges, the rector interviewed mentioned that the number of international students are currently as high as 13000 and increasing despite challenges which forces Georgia to invest in education to stay competitive because this is a market that rewards good universities with good reputations and international recognition.

\subsection{Quality Enhancement Benefitting Local Students}

A third driver seems to be the desire to offer degrees recognized for quality education for Georgian students, for them to be competitive and adaptable. The vice-rector from the capital stressed that the increase in quality is a governmental priority because quality pays for itself; when you offer quality, everybody wants to be partner with you, and students come to you. The rector also stressed that internationalization is not a purpose in itself, in a vacuum, it is really a tool to increase quality through EU funding and academic exchange. He also mentioned that quality needs to be recognized, and this is why Georgia got into EQAR and is making everything possible to achieve recognition. He mentioned multiple efforts made by his and other universities to invite colleagues in Georgia, to increase the visibility of Georgian education and to be on the map of quality education, such as the next meeting of the International Association of University Presidents, which will take place in Georgia. 
For quality to be recognized, the Georgian universities are also taking other steps: two programs at Tbilisi State University received the visit of an accreditation team from the United States in November 2019. The university also prepares to invite the European University Association (EUA) for an institutional visit. The Medical University made efforts to be part of the World Federation of Medical Education (linked with WHO) and achieved a good step towards increasing reputation and recognition of the Georgian medical degrees.

All participants (with two exceptions) mentioned internationalization as a key development towards going up in international university rankings. The former Deputy Minister noted that a sign of the internationalization of Georgian higher education is the presence of Georgian universities in rankings (THE and Shanghai) while other universities from Caucasus countries were absent. To increase their research output and prepare their students for research, one faculty member stated that in her university the majority of faculty desires to be part of internationalization and they voted that doctoral students need to have publications in English in good journals even if this rule is tough for the professors too (the university will try to help them in identifying journals and translating).

\subsection{Restauration of Past Traditions}

A fourth driver mentioned by all participants was Georgia's pre-Soviet tradition of having an elite educated abroad. Most participants view the current drive for internationalization as a way of returning to the traditional cosmopolitan nature of Georgian academics as set up by the founding fathers of local universities. The founder of our school was educated abroad both in Russia and Germany, and many previous scholars were educated in both Russia and Europe (France, Germany). Not only university professors but Georgian cultural elite were always educated abroad and skilled in [foreign] languages. For instance, in 1918 when the first university was established [now Tbilisi State University], all the professors invited to teach were educated in European universities. After the sovietization, all professors with foreign education were not really well accepted, and this is where the tradition broke. Other interviewees mentioned that as soon as it was possible, in the 1980s actually, the universities started to send faculty abroad: re-internationalization in Georgia started in 1988 mostly through students going to study abroad when the first scholarships were offered to students from Georgia (IEC official). A faculty member from a social science department also recounted that: In the late 70 s it became again possible to send some students abroad but in limited numbers. From their department, they could send students in the 80 s in universities from the socialist camp and other nonWestern parts. In the 80s, the first ethnographer was sent to India. Then they were allowed to go to Poland, and other socialist states. But even those countries were limited in terms of what they could offer because they were not at the forefront of disciplinary development. 


\subsection{Professional Development of Faculty}

A fifth driver refers to the desire of faculty to catch up with the trends in their fields, particularly in social sciences which have been politicized or, in some cases (psychology, sociology), even removed from the curriculum. The same senior faculty member describing the early scholarships available in the 1980s reflected that because in the soviet past many things were interrupted, the methodological and content development in social sciences, it is important to catch up. I have been trying constantly to catch up because the time we lost was tragic; there are so many new developments, new methods, we have to constantly try to catch up and keep up.

A more junior faculty member noted that I know there was a gap in us being part of the larger academic world, but I think it has been bridged significantly. I personally feel that I am part of the larger academic world and have the duty to keep up, not to lag behind, and I can do that best through partnerships.

\subsection{Sense of Duty Towards Students}

A sixth driver mentioned by several senior faculty was the duty to offer opportunities they had in the 1990s and 2000s to the students. The state could not fund us 15 years ago, but there were scholars exchange program (ISET/RESET) offered by Open Society Foundation which then supported the creation of new networks: a project called Building Anthropology in Eurasia created a network that still continues and is very useful to this day. These projects changed the world for scholars...they were important for internationalization because it gave Georgian scholars access to top experts in their field. In one project, Harvard University was involved and really top scholars in the field...were involved. These contacts and meetings are very valuable to this day. I experienced that and want my students to experience this opening, but today these programs no longer exist so we need to use the opportunities through EU programs and other international programs (faculty member).

To further illustrate the pressing need to help students, she stated that when I started to develop my career there were not so many students interested in going abroad. There was less competition. Now the Caucasus is not anymore so interesting and this is a limitation for our students. They are more ready because they speak languages, but there is more competition, so we need to help them as others helped us.

\subsection{Support for Research}

Several interviewees both at faculty and university leaders' levels mentioned that internationalization is essential in developing research and in supporting the move 
from faculties dedicated mostly to teaching to those where research plays a major role. The Vice-Rector from the university outside Tbilisi noted that you have to understand that research is very expensive, but it puts you on the map. So far, my university was very good at teaching, but now research has become a priority. The rector from Tbilisi also stressed that without research we cannot go up in rankings, and for research we need to be part of transnational networks. Rankings and research are important to my university, and we need internationalization to boost them, and particularly EU funded projects. A faculty member also noted that to keep the pace with the global academic community is very hard and costly: travelling to conferences, registration fees even if you present papers, publishing, all require funding and through international projects, we can secure this funding.

\subsection{Other Drivers}

Additional drivers for internationalization were mentioned, including institutional and personal ones. The Head of Department from the Ministry of Education indicated that the decrease in population affects Georgian universities, and internationalization is a mean to filling the places that cannot be filled internally. Two faculty members were of the opinion that internationalization is the only way of rooting out faculty without relevant knowledge while other two mentioned the need to open the minds of the society at large by cultural exchanges. The Vice-Rector from the university outside Tbilisi mentioned internationalization as a tool to stand out, to gain visibility which is difficult to attain for a small university outside the capital. In her words maybe countries that give up internationalization have become tired of being famous, but my university, away from the capital, still needs to survive in the big globalized world, and internationalization helps with survival.

To sum up, at policy level, internationalization seems to be driven mainly by the political will to get closer to the EU, with education being one of the tools to achieve a rapprochement. At institutional level, the reasons are several: the aim for quality enhancement through international exchanges, to prepare students for their professional lives in Georgia and abroad and the financial motivation, particularly in medical schools. At a personal level, faculty seems motivated by the desire to catch up professionally - made even more acute in certain disciplines like social sciences (which have been previously marginalized and even prohibited) and engineering (where lack of funding affected the level of technology endowment). Additionally, most faculty mentioned a sense of duty toward students. Some professors work to create for their students travel and research opportunities similar to those they had themselves while others are driven by the belief (supported by research) that students need internationalization to be competitive and to get good jobs. 


\section{Challenges to Internationalization}

Several challenges to internationalization were recurrent in the interviews. Among them are the rigid salary scales at public universities, and the low salaries available for junior professors make it difficult to hire talented graduates of foreign universities, who have better chances for getting a high income in the private universities or outside academia. Also, the limited incentive systems for faculty available for university leaders was often quoted as a major challenge to attracting faculty with foreign degrees and speaking foreign languages, much needed for foreign language programs and for conducting internationally visible research. And the English language competencies are limited among senior Georgian faculty who never studied the language in school, therefore the new hires are essential to internationalization.

Additionally, as the senior leader from San Diego University mentioned, many professors are of retirement age but cannot afford to retire due to the low pension available. Sadly, they are forced to hang on to their positions, cling to their former reputation, and prevent younger colleagues from joining or advancing in the university. This shows that policies such as the pension system, which are not in any way influenced or controlled by universities, have nevertheless an impact on internationalization.

The lack of reform of state university administration was also quoted as an impediment to internationalization, mostly linked to the low salaries available for administrators and their lack of appeal for competent people. Additionally, the vice-rector from the Adjara region noted that they badly need administrators speaking languages because there is a lot of administration in European funded projects, much of it in English... and with students and faculty we can see results of language training but for administrators it is harder.

Several sources also mentioned an overall need for better coordination between ministries dealing with internationalization in addition to a visa system that prevents students from certain countries to attend university. Additionally, the vice-rector from the university outside Tbilisi noted that we do get a lot of support from the local authorities of the region but almost none from the Ministry, not even with visa support. They should spread the word more, try to involve those that are not in Tbilisi more, but I do not see that happening.

The challenges to internationalization reflect national conditions not dissimilar to those in other Central and Eastern European countries (among them Slovakia, Hungary and Romania) where universities are granted limited staffing autonomy. ${ }^{7}$ They also highlight the effect of policies from fields unrelated to education (immigration policy, pension system, the organization of central and local administration) on the activity of university and the push for internationalization. These findings point to the multitude of conditions needed for internationalizing the higher education in countries newer to this trend and the political will required to reform and align policies outside the education system to the internationalization effort.

\footnotetext{
${ }^{7}$ See https://www.university-autonomy.eu/dimensions/staffing/, Consulted January 15, 2020.
} 


\section{Concluding Remarks}

Internationalization in Georgian higher education is driven unsurprisingly by multiple factors among which the political will is a very important one. Not unlike Saakashvili's statements in 2005, the present policy-makers state their desire to be part of the Western sphere and view internationalization of education as an important tool. Georgia is not alone in using higher education to support a new national identity and narrative (Matei et al. 2013 discuss the case of Armenia). Some interviewees linked the need to internationalize with recapturing the spirit of Georgian intelligentsia from pre-Soviet times, a return to a state of normalcy. Others reflect on Georgia being a small country with limited resources to compete in a globalized world.

From official documents and interviews, the general impression is that internationalization is a policy priority, and Georgia is open for relations not just with EU or the US but with countries in the region and beyond. Nevertheless, the sense gathered from the interviews point rather to a selected, targeted internationalization where engaging with their neighbor (and political enemy) Russian Federation is not desired. My research echoes the findings of earlier studies (Toderas and Stavaru 2018, Dobbins and Khachatryan, 2015) and confirms that not much has changed in the academic relations between Georgia and Russia and that this separation continues to be part of the national narrative.

Another finding is the strong support for adhering to European Standards and Guidelines with the view of accessing EU grants needed to finance academic research and exchanges. Internationalization and particularly academic engagement with the EU is seen almost across the board at all levels as a tool to increase quality through EU funding and academic exchange. For this reason, Georgia has been active in EU funded research programs, ranking number 10 in terms of activity among all nonEU countries. Most interviewees noted that Georgia is to a large extent forced to internationalize because the national budget is insufficient to independently support the desired development of the higher education sector. The power of EU's purse (Bathory and Lindstrom 2011) provides, therefore, a strong incentive for Georgia to open up in order to attract funding. Building on resources dependency theory (Pfeffer and Salancik 1978) we could advance the conclusion that EU resources are vital to Georgian research, and therefore internationalization is as much a choice as it is a need.

Increasing research output is also needed to improve the standing in rankings, where Georgia is doing better than the rest of the Caucasus neighbours but equally struggling as most of Eastern European countries for the same reasons (Boyadjieva 2017): a history of universities as teaching places and academies of sciences as research places, limited funding to higher education, language limitations and the added burden of a turbulent recent past.

As pointed out by a faculty member and an administrator, the internationalization of higher education seems to be also externally driven or supported or even desired by external partners: the US has supported the Millennium Challenge which financed 
the establishment of the Tbilisi campus of San Diego University as a way to support STEM education in Georgia. The American university partnered with three Georgian universities, Georgian Technical University (GTU), Ilia State University (ISU), and Tbilisi State University (TSU) to offer internationally recognized undergraduate degrees. Additionally, other initiatives like the one funded by the German government through GIZ support internationalization through funding academic exchange programs.

To conclude, Georgia's reasons for internationalization are very much part of the effort of enforcing a pro-European and pro-Western national identity and educating citizens in this spirit. The main arguments against internationalization that led to a reversal of policy in parts of Europe are not present in Georgia: the state funding is used primarily to cover the costs incurred by national students, the foreign students rarely remain to work in the country, and students from certain countries cannot even enter the educational system; therefore the argument of foreigners taking local jobs or abusing local resources is not present. The only drawback to internationalization mentioned by four out of 17 interviews is the loss of Georgian language as an academic language if internationalization continues, but universities try to address this concern by including solely readings in Georgian at undergraduate level and making efforts to translate into Georgian key research articles published in English. In brief, Georgian academics and policy-makers see that the benefits brought by internationalization far outweigh the potential disadvantages.

\section{References}

Altbach, P., \& de Wit, H. (2018). Are We Facing a Fundamental Challenge to Higher Education Internationalization? International Higher Education, (93), 2-4.

Bathory, A., \& Lindstrom, N. (2011). The power of the purse: Supranational entrepreneurship, financial incentives, and European higher education policy. Governance, 24(2), 311-329.

Boyadjieva, P. (2017). Invisible higher education: Higher education institutions from Central and Eastern Europe in global rankings. European Educational Research Journal, 16(5), 529-546.

Campbell, A. C. (2016). International Scholarship Graduates Influencing Social and Economic Development at Home: The Role of Alumni Networks in Georgia and Moldova. Current Issues in Comparative Education, 19(1), 76-91.

Campbell, A., \& Gorgodze, S. (2016). Internationalization of Georgian higher education: National and international influences. Hungarian Educational Research Journal, 1.

De Wit, H., Hunter, F., Howard, \& L., Egron-Polak, E. (2015). Internationalisation of higher education. European Parliament, Policy Department B: Structural and Cohesion Policies. Retrieved from http://www.europarl.europa.eu/RegData/etudes/STUD/2015/540370/ IPOL_STU(2015)540370_EN.pdf. accessed Jan-uary 15, 2020

Dobbins, M., \& Khachatryan, S. (2015). Europeanization in the "Wild East"? Analyzing higher education governance reform in Georgia and Armenia. Higher Education, 69(2), 189-207.

Jawad, P. (2005). Democratic consolidation in Georgia after the "Rose Revolution"?

Jibladze, E. (2017). Reforms for the external legitimacy in the post Rose Revolution Georgia: Case of university autonomy. Hungarian Educational Research Journal, 7(1), 7-27.

Kehm, B. M., \& Teichler, U. (2007). Research on internationalisation in higher education. Journal of studies in international education, 11(3-4), 260-273. 
Knight, J. (2003). Updated definition of internationalization. International higher education, (33). Knight, J. (2004). Internationalization remodeled: Definition, approaches, and rationales. Journal of studies in international education, 8(1), 5-31.

Kovács, K. (2014). The Bologna process in the Ukraine. In The Bologna Process in Central and Eastern Europe (pp. 321-353). Springer VS, Wiesbaden.

Matei, L., Iwinska, J., \& Geven, K. (2013). Higher education in Armenia today: A focused review. Report for the Open Society Foundation Armenia. Budapest: CEU Higher EducationObservatory.

Meyer, J. W., and Rowan, B. (1977). "Institutionalized organizations: Formal structure as myth and ceremony," American Journal of Sociology 83:340-363.

Nastase, P. (2015). University fund-raising in Romania: sermon and institutional myth (Doctoral dissertation, University of Bristol).

Pfeffer, J., \& Salancik, G. R. (1978). The extemal control of organizations. A Resource Dependence Perspective, New York et al.: Harper \& Row. Saakashvili, M. (2006). The Way Forward. Harvard International Review, 28(1), 68.

Sharvashidze, G. (2005). Private higher education in Georgia. International Institute for Educational Planning.

Toderas, N., \& Stăvaru, A. M. (2018). The Impact of the Bologna Process on the Governance of Higher Education Systems in Eastern Partnership Countries. In European Higher Education Area: The Impact of Past and Future Policies (pp. 707-721). Springer, Cham.

Open Access This chapter is licensed under the terms of the Creative Commons Attribution 4.0 International License (http://creativecommons.org/licenses/by/4.0/), which permits use, sharing, adaptation, distribution and reproduction in any medium or format, as long as you give appropriate credit to the original author(s) and the source, provide a link to the Creative Commons license and indicate if changes were made.

The images or other third party material in this chapter are included in the chapter's Creative Commons license, unless indicated otherwise in a credit line to the material. If material is not included in the chapter's Creative Commons license and your intended use is not permitted by statutory regulation or exceeds the permitted use, you will need to obtain permission directly from the copyright holder.

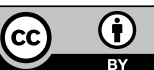

